\title{
Effect of acetylator phenotype on efficacy and toxicity of sulphasalazine in rheumatoid arthritis
}

\author{
T PULLAR, ${ }^{1}$ J A HUNTER, ${ }^{2}$ H A CAPELL ${ }^{1}$
}

From the ${ }^{1}$ University Department of Medicine, Centre for Rheumatic Diseases, Wards 14/15, Glasgow Royal Infirmary, Glasgow G4 OSF; and ${ }^{2}$ Gartnavel General Hospital, Glasgow G12 OYN

SUMmARY A group of 54 patients with rheumatoid arthritis (31 fast, 23 slow acetylators) treated with sulphasalazine $3 \mathrm{~g} /$ day were studied retrospectively. At 24 weeks no difference in the efficacy of the drug could be shown between fast and slow acetylators. In a second prospective study 40 fast acetylators were allocated to $3 \mathrm{~g} /$ day and 20 slow acetylators to $1.5 \mathrm{~g} / \mathrm{day}$. At 24 weeks marked improvement was seen in the fast acetylators given high dose but not the slow acetylators given low dose. It was also noted in this study that the usual ratio of fast : slow acetylators was reversed, and there is some suggestion that fast acetylators may be predisposed to more severe rheumatoid arthritis. The toxicity pattern in a total of 149 patients ( 83 fast, 66 slow acetylators) was also studied. Significantly more slow acetylators stopped treatment because of nausea or vomiting, or both, but serious toxicity was not confined to either group. Acetylator phenotype therefore appears important in determining the incidence of nausea and/or vomiting associated with sulphasalazine therapy in patients with rheumatoid arthritis but has no effect on the occurrence of potentially serious toxicity or efficacy. Thus prior measurement of acetylator phenotype in patients with rheumatoid arthritis confers little practical benefit in their management.

Key words: pharmacogenetics, second-line antirheumatic drugs.

Sulphasalazine has recently been resurrected as a second-line drug and has been shown to be effective in the treatment of rheumatoid arthritis. ${ }^{1-5}$

Sulphasalazine is the azo ester of sulphapyridine and 5-aminosalicylic acid (5-ASA). Only a small proportion (about 7\%) is absorbed as sulphasalazine, and the remainder reaches the large intestine, where it is split by bacterial action at its azo bond into the constituent components. The 5-ASA remains largely within the large bowel and is excreted in the faeces unchanged. Only a small amount of 5-ASA reaches the systemic circulation, and in patients with ulcerative colitis peak serum levels reach only $1-4 \mu \mathrm{g} / \mathrm{ml}(\mathrm{mg} / \mathrm{l})$. Sulphapyridine, on the other hand, is almost totally absorbed and is eventually excreted in the urine either unchanged or after hepatic metabolism. The major hepatic metabolites are in the acetylated form, though glucuronation and hydroxylation also occur. Sul-

Accepted for publication 14 May 1985.

Correspondence to $\mathrm{Dr} T$ Pullar, University Department of Medicine, Martin Wing. The General Infirmary, Leed LS1 3EX. phapyridine is excreted in the urine more rapidly in the metabolised form. ${ }^{6}$ Acetylation occurs by means of hepatic (and perhaps intestinal wall) $N$ acetyltransferase. The rate of acetylation is genetically determined and follows a bimodal distribution, resulting in individuals being classed as either slow of fast acetylators. Other drugs with similar genetically determined rate of acetylation include hydralazine, procainamide, dapsone, isoniazid, other sulphonamides, phenelzine, and nitrazepam. ${ }^{7}$ In the United Kingdom approximately $40 \%$ of the population have been reported to be fast acetylators and $60 \%$ slow acetylators. ${ }^{8}$ In slow acetylators the serum half life of sulphapyridine is almost three times greater than in fast acetylators, ${ }^{9}$ though there is some controversy about the effect of acetylator phenotype on the steady state serum levels of sulphapyridine and its metabolites. ${ }^{10-13}$ There is good evidence, however, in both patients with ulcerative colitis and healthy volunteers that adverse effects occur more commonly in slow acetylators. $^{1214}$ 
In this paper we examine the effect of acetylator phenotype on the efficacy and toxicity of sulphasalazine in rheumatoid arthritis and examine whether allocation to different doses on the basis of acetylator phenotype improves the therapeutic ratio of the drug.

\section{Patients and methods}

A summary of the various patient groups studied is given in Table 1.

All patients studied suffered from classical or definite rheumatoid arthritis which remained clinically active despite optimum dosage of non-steroidal anti-inflammatory drugs (NSAIDs) and required the addition of a second-line agent in an attempt to control disease activity. As far as possible patients remained on the same NSAID at a constant dose throughout the study. No patients had known sulphonamide or salicylate sensitivity, and none had previously received sulphasalazine. Apart from two patients in study 4 (Table 1) no patients were taking or had ever taken corticosteroids for their rheumatoid arthritis, and none took other second-line drugs during the study or in the preceding three months.

All patients started on sulphasalazine (enteric coated) $0.5 \mathrm{~g} /$ day, and the dose was increased by weekly increments of $0.5 \mathrm{~g} /$ day until the allocated dose was achieved or dose related toxicity was encountered. If after 18 weeks no benefit had been achieved the dose could be increased to a maximum of $4 \mathrm{~g} /$ day.

The four studies described were carried out in the same centre over a three-year period. The physician treating the patients and the clinical research nurse who carried out blind assessments were the same throughout.

Analysis of the relationship between acetylato phenotype and efficacy was carried out in twe groups of patients - one retrospective (comprising the 60 patients randomly allocated to sulphasalazine $3 \mathrm{~g} /$ day in studies 1 and 2) and one prospective (study 3 ). In addition we have reviewed the effect 0 里 acetylator phenotype on toxicity of sulphasalazine if all patients shown in Table 1 in whom acetylator phenotype was available, i.e., 149 out of the total of 158.

RETROSPECTIVE STUDY GROUP

In this group acetylator phenotype was assesse retrospectively by one of the methods described in Table 2. Patients who, at the time of phenotyping were still receiving sulphasalazine had acetylatow phenotype calculated from either the serum o $\vec{j}$ urinary ratios of acetylated sulphapyridine : tota sulphapyridine. ${ }^{16} 17$ Those who had discontinued sulphasalazine before phenotyping was carried out had their acetylator phenotype assessed b $\Phi$ sulphadimidine $^{8}$ if they were not sulphonamide sensitive and by isoniazid ${ }^{18}$ if sulphonamide sensitive ity seemed likely.

Efficacy of sulphasalazine was assessed at 290 weeks, and the results of the individual studies have been reported separately. ${ }^{4} 15$

PROSPECTIVE GROUP

Sixty patients (study 3 in Table 1) had acetylato phenotype assessed by an oral dose of sulphadim dine $(10 \mathrm{mg} / \mathrm{kg})^{8}$ before starting sulphasalazineo Slow acetylators were then allocated to sulphasala

Table 1 Summary of various studies of sulphasalazine described in this paper

\begin{tabular}{|c|c|c|c|c|c|c|}
\hline Study & $\begin{array}{l}\text { No of } \\
\text { patients }\end{array}$ & $\begin{array}{l}\text { Allocated } \\
\text { dose }\end{array}$ & $\begin{array}{l}\text { Method of } \\
\text { allocation }\end{array}$ & $\begin{array}{l}\text { Aim of } \\
\text { study }\end{array}$ & Comments & $\begin{array}{l}\text { No of patients with } \\
\text { acetylator phenotype } \\
\text { available }\end{array}$ \\
\hline \multirow[t]{2}{*}{$1^{4}$} & $\begin{array}{l}30 \\
30\end{array}$ & $\begin{array}{l}3.0 \mathrm{~g} / \mathrm{day} \\
\text { Sodium } \\
\text { aurothiomalate } \\
50 \mathrm{mg} / \text { week }\end{array}$ & \multirow[t]{2}{*}{ Random } & \multirow[t]{2}{*}{$\begin{array}{l}\text { Comparison of efficacy of } \\
\text { sulphasalazine with that of } \\
\text { gold and of placebo }\end{array}$} & \multirow[t]{2}{*}{ - } & 28 \\
\hline & 30 & $\begin{array}{l}\text { Placebo } \\
6 \text { tabs/day }\end{array}$ & & & & 一 \\
\hline $2^{15}$ & $\begin{array}{l}30 \\
30\end{array}$ & $\begin{array}{l}1.5 \mathrm{~g} / \text { day } \\
3.0 \mathrm{~g} / \text { day }\end{array}$ & Random & $\begin{array}{l}\text { Comparison of efficacy and } \\
\text { toxicity of two doses of } \\
\text { sulphasalazine }\end{array}$ & - & $\begin{array}{l}27 \\
26\end{array}$ \\
\hline 3 & $\begin{array}{l}20 \\
40\end{array}$ & $\begin{array}{l}1.5 \mathrm{~g} / \text { day } \\
3.0 \mathrm{~g} / \text { day }\end{array}$ & $\begin{array}{l}\text { Slow acetylators } \\
\text { Fast acetylators }\end{array}$ & $\begin{array}{l}\text { To test the hypothesis that } \\
\text { slow acetylators require } \\
\text { a smaller dose }\end{array}$ & - & $\begin{array}{l}20 \\
40\end{array}$ \\
\hline 4 & 8 & $3.0 \mathrm{~g} / \mathrm{day}$ & $>65$ years old & $\begin{array}{l}\text { To define pharmacokinetics } \\
\text { in an elderly population }\end{array}$ & $\begin{array}{l}\text { Median age } \\
74 \text { years } \\
\text { (range } 65-80 \text { ) }\end{array}$ & 8 \\
\hline
\end{tabular}




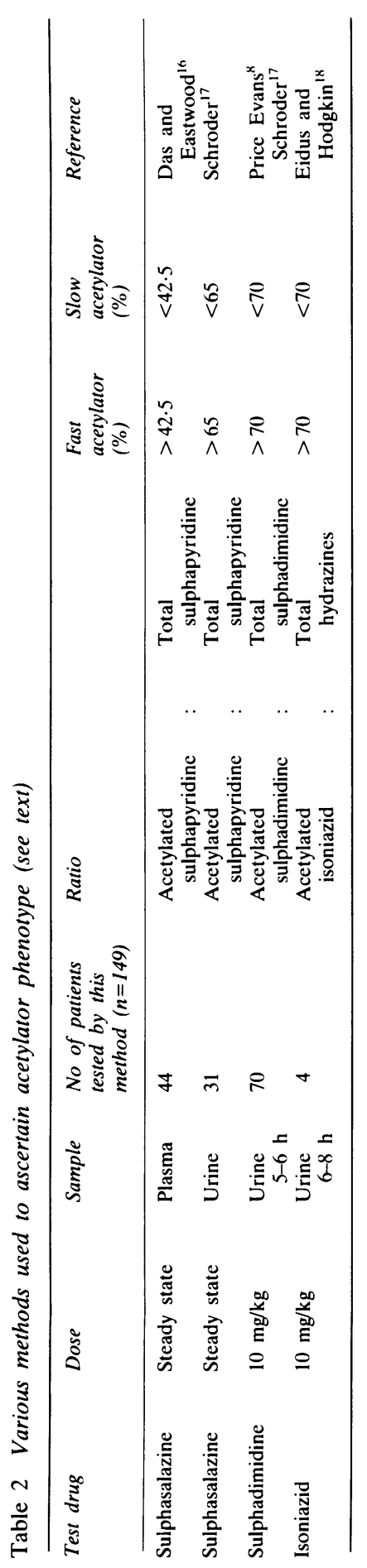

zine (enteric coated) $1.5 \mathrm{~g} /$ day and fast acetylators to $3 \mathrm{~g} /$ day. The dose of $3 \mathrm{~g} /$ day was chosen as this is our standard clinical dose. $1.5 \mathrm{~g} /$ day for the slow acetylators was chosen arbitrarily, but it is the "low dose' that we used previously in a study comparing doses. ${ }^{15}$ Assessment of efficacy was carried out at 24 weeks.

TOXICITY STUDY

Acetylator phenotype was assessed in the 149 of the total 158 patients so far treated with sulphasalazine and described in Table 1 in whom acetylator phenotype was available. These patients were followed up for 24 weeks.

ST A T IS T I CS

Appropriate non-parametric statistics were used throughout.

\section{Results}

RETROSPECTIVE GROUP

Acetylator phenotype was available in 54 of the 60 patients. Thirty-one $(57 \%)$ were defined as fast acetylators and $23(43 \%)$ as slow acetylators. By 24 weeks $19(61 \%)$ fast and $16(70 \%)$ slow acetylators remained on treatment. Inefficacy led to discontinuation of therapy in three of the fast acetylator group but in none from the slow acetylator group. Most patients who remained on therapy achieved their allocated dose of $3 \mathrm{~g} /$ day (Table 3 ).

Clinical and laboratory parameters of inflammation and of toxicity are shown in Table 4 . At week 0 there were no significant differences between the two groups (Mann-Whitney $U$ test, $p>0.05$ ). Both slow and fast acetylators showed a statistically significant improvement in most inflammatory indices, and no significant differences could be shown between slow and fast acetylators for either the 24-week values or the degree of change (MannWhitney $U$ test, $\mathrm{p}>0 \cdot 05$ ).

PROSPECTIVE GROUP

Forty patients $(66 \%)$ were fast acetylators and thus allocated to $3 \mathrm{~g} /$ day and $20(33 \%)$ were slow acetylators and thus given $1.5 \mathrm{~g} / \mathrm{day}$. At 24 weeks 15 $(75 \%)$ slow acetylators and $27(68 \%)$ fast acetylators remained on treatment, again most achieved their allocated dose (Table 3). One patient in the fast acetylator group stopped because of inefficacy. Unfortunately the slow acetylator/low dose group had a significantly lower erythrocyte sedimentation rate (ESR) and C-reactive protein (CRP) and higher haemoglobin (Mann-Whitney $U$ test, $p<0.001$ ) at the outset of therapy. Other parameters, however, were comparable (Mann-Whitney U test, $\mathrm{p}>0 \cdot 05$ ). Improvement over the study period was more 
readily shown in the fast acetylator/high dose group (Table 5), and the percentage fall in ESR was significantly greater in this group (Mann-Whitney U test, $\mathrm{p}<0.05$ ). Twelve high dose but only three low dose patients achieved $\geqslant 50 \%$ improvement in ESR: Fig. 1 illustrates graphically the change in median ESR in the two. By week 24 any differences between the groups were lost (Mann-Whitney test, $\mathrm{p}>0 \cdot 05)$.

TOXICITY DATA

Of the total 149 patients in whom acetylatos phenotype was available $83(56 \%)$ were fast and $6 \%$ $(44 \%)$ were slow acetylators. Of the nine patients in

Table 3 Actual 24-week dose in various patient groups

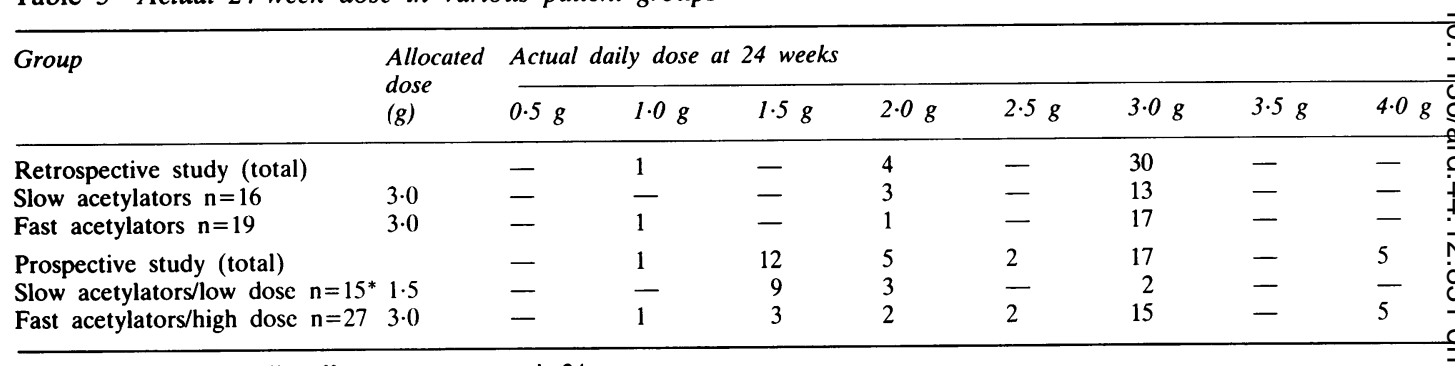

*One patient temporarily off treatment at week 24 .

Table 4 Medians (with ranges) for various indices at weeks 0 and 24 for patients allocated to $3 \mathrm{~g}$ sulphasalazine a da (retrospective study)

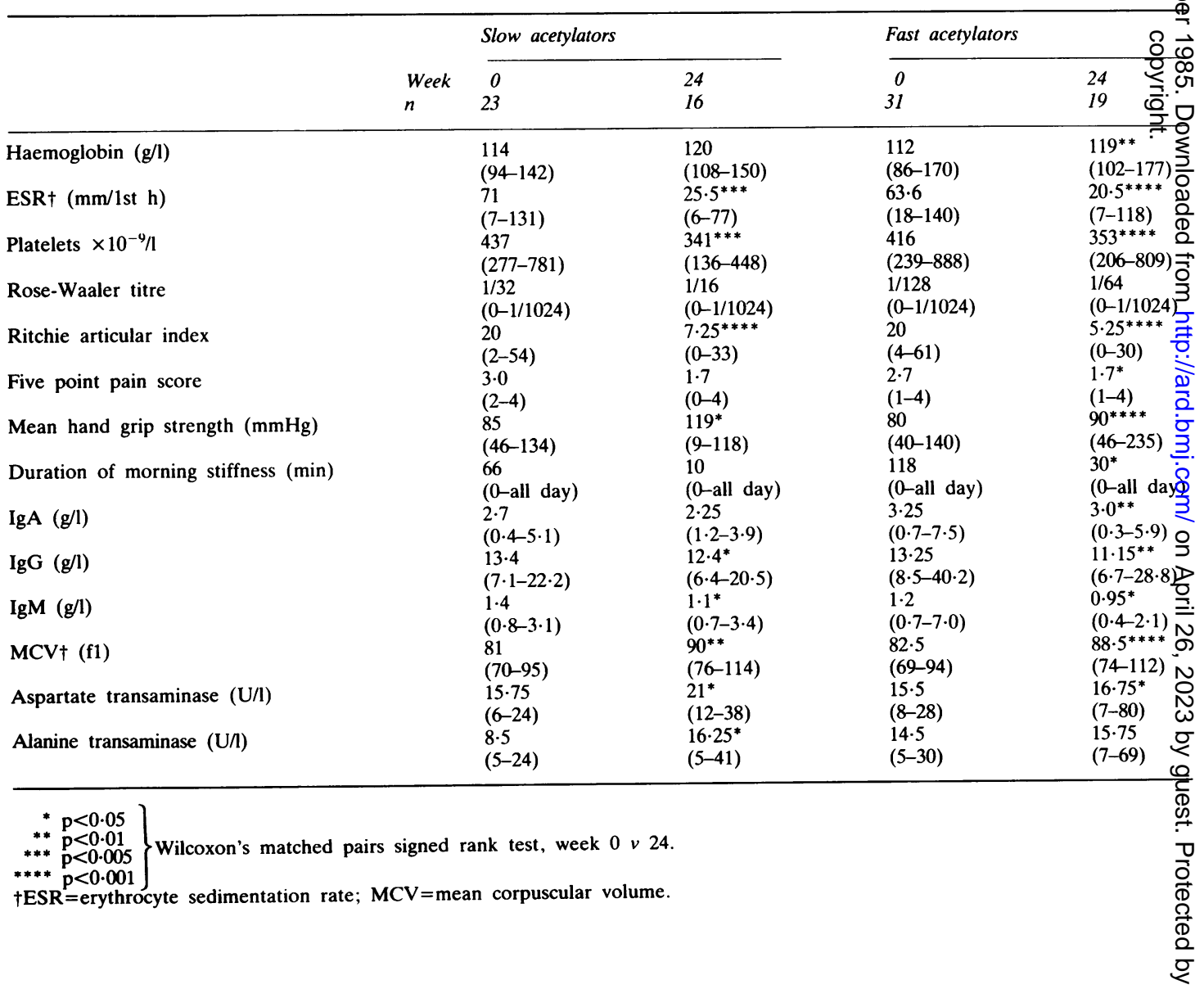




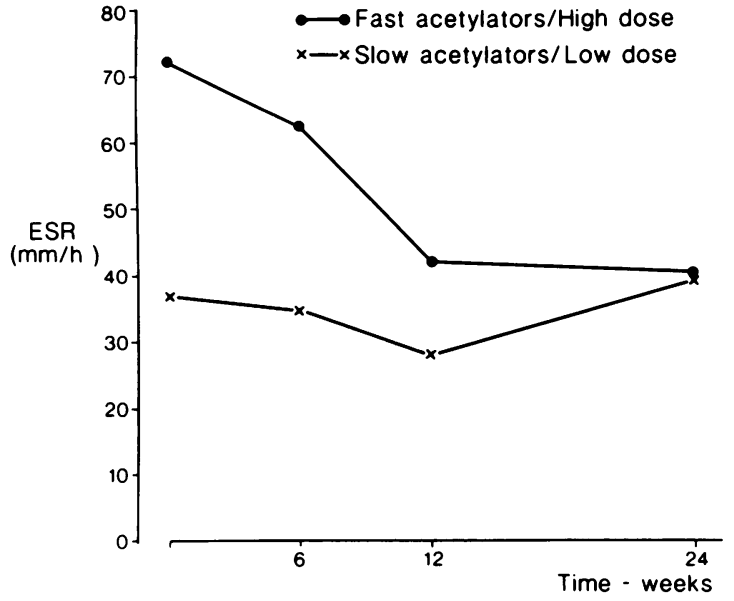

Fig. 1 Median ESR in the slow acetylator/low dose and the fast acetylator/high dose groups. whom acetylator phenotype was not available one had died a non-drug-related death, one had left the area, four refused to co-operate, and three had equivocal results making classification as slow or fast impossible. Toxicity rates in fast and slow acetylators were compared. Table 6 shows the reason for discontinuing therapy in the two groups over 24 weeks. Twenty-one (32\%) out of 66 slow acetylators and $23(28 \%)$ out of 83 fast acetylators $\left(\chi^{2}=0.293\right.$, $\mathrm{p}>0.05$ ) discontinued therapy before 24 weeks. In total, 18 stopped because of nausea and/or vomiting, 13 slow and five fast acetylators $\left(\chi^{2}=6 \cdot 35, p<0 \cdot 02\right)$. No difference could be seen, however, in the overall rate of drop out because of all toxic events $\left(\chi^{2}=1 \cdot 30\right.$, $p>0.05)$. In addition, Tables 4 and 5 show the results of hepatic transaminases and mean red cell volume (MCV) over the study period. Although values for these indices rose in the patients receiving $3 \mathrm{~g} /$ day, no differential effect of acetylator

Table 5 Medians (with ranges) for study 3 patients, i.e., fast acetylators allocated to high dose and slow acetylators allocated to low dose

\begin{tabular}{|c|c|c|c|c|c|}
\hline & \multirow[b]{2}{*}{$\begin{array}{l}\text { Week } \\
n\end{array}$} & \multicolumn{2}{|c|}{ Slow acetylators/low dose } & \multicolumn{2}{|c|}{ Fast acetylators/high dose } \\
\hline & & $\begin{array}{r}0 \\
20\end{array}$ & $\begin{array}{l}24 \\
15\end{array}$ & $\begin{array}{r}0 \\
40\end{array}$ & $\begin{array}{l}24 \\
27\end{array}$ \\
\hline Haemoglobin $(g / l)$ & & $\begin{array}{l}123 \\
(74-161)\end{array}$ & $\begin{array}{l}124 \\
(71-152)\end{array}$ & $\begin{array}{l}114 \\
(78-166)\end{array}$ & $\begin{array}{l}115 \\
(86-171)\end{array}$ \\
\hline $\mathrm{ESR} \dagger(\mathrm{mm} / 1 \mathrm{st} \mathrm{h})$ & & $\begin{array}{l}37 \cdot 5 \\
(2-125)\end{array}$ & $\begin{array}{l}39 \cdot 5 \\
(2-115)\end{array}$ & $\begin{array}{l}73 \\
(10-150)\end{array}$ & $\begin{array}{l}40^{* * * *} \\
(5-105)\end{array}$ \\
\hline Platelets $\times 10^{-9} /$ & & $\begin{array}{l}355 \\
(118-607)\end{array}$ & $\begin{array}{l}322 \\
(143-502)\end{array}$ & $\begin{array}{l}421 \\
(126-802)\end{array}$ & $\begin{array}{l}295^{* * * * *} \\
(202-754)\end{array}$ \\
\hline Rose-Waaler titre & & $\begin{array}{l}1 / 256 \\
(0-1 / 1024)\end{array}$ & $\begin{array}{l}1 / 16 \\
(0-1 / 1024)\end{array}$ & $\begin{array}{l}1 / 512 \\
(0-1 / 1024)\end{array}$ & $\begin{array}{l}1 / 128^{*} \\
(0-1 / 1024)\end{array}$ \\
\hline Ritchie articular index & & $\begin{array}{l}17 \cdot 5 \\
(2-39)\end{array}$ & $\begin{array}{l}8 \cdot 5^{* * *} \\
(0-23)\end{array}$ & $\begin{array}{l}16 \\
(0-39)\end{array}$ & $\begin{array}{l}6 \cdot 0 * * * * \\
(0-21)\end{array}$ \\
\hline Five point pain score & & $\begin{array}{l}2 \cdot 4 \\
(1-4)\end{array}$ & $\begin{array}{l}1 \cdot 9 \\
(1-4)\end{array}$ & $\begin{array}{l}2 \cdot 7 \\
(1-4)\end{array}$ & $\begin{array}{l}1 \cdot 7^{* * * * *} \\
(1-4)\end{array}$ \\
\hline Mean hand grip strength $(\mathrm{mmHg})$ & & $\begin{array}{l}67 \cdot 5 \\
(39-167)\end{array}$ & $\begin{array}{l}70 \cdot 5 \\
(36-243)\end{array}$ & $\begin{array}{l}83 \cdot 5 \\
(38-190)\end{array}$ & $\begin{array}{l}91 \cdot 5^{*} \\
(45-240)\end{array}$ \\
\hline Duration of morning stiffness (min) & & (0-all day) & $\begin{array}{l}75 \\
\text { (0-all day) }\end{array}$ & $\begin{array}{l}76 \\
\text { (0-all day) }\end{array}$ & $\begin{array}{l}30^{* * * *} \\
\text { (0-all day) }\end{array}$ \\
\hline $\operatorname{IgA}(g / l)$ & & $\begin{array}{l}3 \cdot 1 \\
(1 \cdot 2-6 \cdot 3)\end{array}$ & $\begin{array}{l}2 \cdot 3 \\
(1 \cdot 1-6 \cdot 2)\end{array}$ & $\begin{array}{l}3 \cdot 2 \\
(0 \cdot 3-6 \cdot 5)\end{array}$ & $\begin{array}{l}2 \cdot 7^{* * * * *} \\
(0 \cdot 2-5 \cdot 3)\end{array}$ \\
\hline IgG (g/l) & & $\begin{array}{l}12 \cdot 3 \\
(9 \cdot 3-23 \cdot 6)\end{array}$ & $\begin{array}{l}10 \cdot 9 \\
(4 \cdot 7-18)\end{array}$ & $\begin{array}{l}14 \cdot 4 \\
(6 \cdot 2-24 \cdot 4)\end{array}$ & $\begin{array}{l}10 \cdot 4^{* * * *} \\
(4 \cdot 3-20 \cdot 9)\end{array}$ \\
\hline $\operatorname{IgM}(g / 1)$ & & $\begin{array}{l}1 \cdot 1 \\
(0 \cdot 6-3 \cdot 7)\end{array}$ & $\begin{array}{l}1 \cdot 1 \\
(0 \cdot 3-3 \cdot 0)\end{array}$ & $\begin{array}{l}1.4 \\
(0.4-9.9)\end{array}$ & $\begin{array}{l}1 \cdot 2^{* * *} \\
(0 \cdot 2-3 \cdot 3)\end{array}$ \\
\hline C-reactive protein & & $\begin{array}{l}25 \cdot 5 \\
(6 \cdot 0-40 \cdot 1)\end{array}$ & $\begin{array}{l}13 \cdot 9 \\
(6 \cdot 0-62 \cdot 1)\end{array}$ & $\begin{array}{l}40 \cdot 5 \\
(6 \cdot 0-100)\end{array}$ & $\begin{array}{l}10 \cdot 7^{* *} \\
(6 \cdot 0-42 \cdot 1)\end{array}$ \\
\hline $\operatorname{MCV}(\mathbf{f l})$ & & $\begin{array}{l}85 \\
(71-102)\end{array}$ & $\begin{array}{l}87 \\
(69-100)\end{array}$ & $\begin{array}{l}81 \\
(66-93)\end{array}$ & $\begin{array}{l}85^{* * * * *} \\
(75-98)\end{array}$ \\
\hline Aspartate transaminase (U/l) & & $\begin{array}{l}13 \\
(6-21)\end{array}$ & $\begin{array}{l}15 \cdot 5 \\
(8-301)\end{array}$ & $\begin{array}{l}18 \\
(10-39)\end{array}$ & $\begin{array}{l}21^{*} \\
(10-104)\end{array}$ \\
\hline Alanine transaminase $(U / 1)$ & & $(4-31)$ & $\begin{array}{l}12 \cdot 5 \\
(5-282)\end{array}$ & $\begin{array}{l}15 \\
(3-40)\end{array}$ & $\begin{array}{l}16 \\
(7-42)\end{array}$ \\
\hline
\end{tabular}

\footnotetext{
$* \mathrm{p}<0.05$

$* * \mathrm{p}<0.01$

$* * * \mathrm{p}<0.005$

$* * * * \mathrm{p}<0.001$

Wilcoxon's matched pairs signed rank test, week $0 v 24$
} 
Table 6 Reasons for and week of discontinuing therapy over first 24 weeks treatment

\begin{tabular}{|c|c|c|c|c|}
\hline \multirow[t]{2}{*}{ Reason for stopping } & \multicolumn{2}{|c|}{ Slow acetylators $(n=66)$} & \multicolumn{2}{|c|}{ Fast acetylators $(n=83)$} \\
\hline & No stopped & Week stopped & No stopped & Week stopped \\
\hline Nausea/vomiting & $13(20 \%)$ & $\begin{array}{l}3,3,3,4,4,4,6 \\
6,6,8,12,12,18\end{array}$ & $5(6 \%)$ & $3,6,6,12,{ }^{*} 20$ \\
\hline Leucopenia & $2(3 \%)$ & 6,10 & $4(5 \%)$ & $1,4,8,10$ \\
\hline Rash & $2(3 \%)$ & 1,18 & $2(2 \%)$ & 9,11 \\
\hline Mouth ulcers & 0 & & $2(2 \%)$ & 1,2 \\
\hline Drowsiness & $1(1 \cdot 5 \%)$ & 8 & 0 & \\
\hline Dizziness & 0 & & $2(2 \%)$ & $6,12^{*}$ \\
\hline Hepatitis & 0 & & $1(1 \%)$ & 18 \\
\hline Lack of efficacy & 0 & & $5(6 \%)$ & $18,18,24,24,24$ \\
\hline Poor compliance & $1(1 \cdot 5 \%)$ & 6 & 0 & \\
\hline Intercurrent illness & $1(1 \cdot 5 \%)$ & 10 & 0 & \\
\hline Other & $1(1.5 \%)$ & 4 & $3(3 \cdot 5 \%)$ & $6,6,18$ \\
\hline Total & $21(32 \%)$ & & $23(28 \%)$ & \\
\hline
\end{tabular}

* Same patient.

phenotype was shown (Mann-Whitney $U$ test, $\mathrm{p}>0.05)$. There was no statistically significant rise, however, in the slow acetylator/low dose group.

\section{Discussion}

In this paper we aimed to assess whether acetylator phenotype affects the toxicity and efficacy of sulphasalazine in rheumatoid arthritis. It would appear that acetylator phenotype does influence the incidence of drop out because of upper gastrointestinal symptoms, with a significantly higher incidence in slow acetylators. Statistical significance was not achieved, however, when the total number of drop outs for all reasons or for all toxic events were compared. This suggests that although nausea/ vomiting is related to acetylator phenotype, other toxic events are not.

This higher incidence of nausea and/or vomiting in slow acetylators is what might be expected from a study of the literature on inflammatory bowel disease and normals. ${ }^{12} 14$ In many instances, however, patients with rheumatoid arthritis are known to react differently from other patients to a number of drugs, and it is therefore important to confirm this relationship between slow acetylator phenotype and symptoms of nausea and/or vomiting in rheumatoid arthritis. It is also of interest to note that rheumatoid patients who were slow aceytlators did not appear to show any increased toxicity with dapsone. ${ }^{19}$

The data on efficacy are unfortunately less clear cut. Probably the simplest and, to those patients concerned, the most important measure of inefficacy is the proportion of patients who failed to complete the follow-up period because of continued severe arthritic symptoms (five $(6 \%)$ fast acetyla=tors, no slow acetylators). Such a difference be tween groups, however, does not achieve statistica\$ significance, but more conclusive results might be्ठ obtained from a larger series. The retrospective dat $\mathbb{P}$ failed to show any advantages in terms of effic\&cy related to one particular acetylator phenotype 9100 the prospective study the fast acetylators/high dosse patients showed improvement in more indices, though slow acetylators/low dose patients had ins itially less active disease, the groups were indis tinguishable in terms of disease activity at 24 weekso This suggests that the higher dose might bring abou@ a more favourable response even in fast acetylators $\overrightarrow{\vec{Q}}$ and the percentage improvement in ESR wað greater in this group. Overall, these findings imple that any effect of acetylator phenotype on the efficacy of sulphasalazine is minor and is faw outweighed by the effect of the dose. This rela? tionship of dose to efficacy has been previousl $\underline{B}$ described. ${ }^{15}$

Inclusion of retrospective data in these studies may invite criticism. However, data were only retrospective in as much as acetylator phenotype was assessed either during or after treatment, and al patients described were assessed by clinical and. laboratory methods under clinical trial conditions inf consecutive studies. A number of methods of assessing acetylator phenotype were used, but the literature indicates that correlation between these methods is excellent. ${ }^{16}{ }^{17}$ Previous work has show the sulphapyridine moiety to be the active compor nent of sulphasalazine, ${ }^{20}$ but although dose of sulphasalazine is related to efficacy, there is no relationship between serum levels of unaltere sulphapyridine and the efficacy of the drug. ${ }^{15}$ The्ष 
finding that acetylator phenotype is of little importance in determining efficacy provides further evidence for the hypothesis that a metabolite of sulphapyridine may be active or the site of action is not in equilibrium with the blood pool.

It is also noteworthy that the previously reported UK ratio of slow:fast acetylators was reversed in this study. This may suggest an ethnic difference or a difference in the rheumatoid population. Previous work in Glasgow has shown no difference in the ratio of slow:fast acetylators either in normals or in rheumatoid patients ${ }^{21}$ when compared with earlier English studies. ${ }^{8}$ Thus the reversed ratio in our case may merely be accident or may reflect a preponderance of fast acetylators among patients with rheumatoid arthritis severe enough to require second-line drugs. The latter possibility is lent some credence by the fact that in study 3 slow acetylators had milder disease.

In summary, patients with rheumatoid arthritis who are slow acetylators are more likely to stop therapy because of nausea/vomiting, but the overall drop out rate does not differ from that of fast acetylators. In addition, no statistically significant difference in efficacy could be shown between fast and slow acetylators. Thus routine assessment of acetylator phenotype before commencement of sulphasalazine does not appear to have practical value.

\section{References}

1 McConkey B, Amos R S, Butler R A, et al. Salazopyrin in rheumatoid arthritis. Agents Actions 1978; 8: 438-41.

2 McConkey B, Amos R S, Durham S, Forster P J G, Hubball S, Walsh L. Sulphasalazine in rheumatoid arthritis. Br Med J 1980; 280: $442-4$.

3 Bird H A, Dixon J S, Pickup M E, et al. A biochemical assessment of sulphasalazine in rheumatoid arthritis. $J$ Rheuma tol 1982; 9: 36-45.

4 Pullar T, Hunter J A, Capell H A. Sulphasalazine in rheumatoid arthritis : a double blind comparison of sulphasalazine with placebo and sodium aurothiomalate. Br Med J 1983; 287: 1102-4.
5 Neumann V C, Grindulis K A, Hubball S, McConkey B, Wright V. Comparison between penicillamine and sulphasalazine in rheumatoid arthritis. Leeds-Birmingham trial. $\mathrm{Br}$ Med J 1983; 287: 1099-102.

6 Das K H, Dubin R. Clinical pharmacokinetics of sulphasalazine. Clin Pharmacokinet 1976; 1: 406-25.

7 Lunde P K M, Frislid K. Hansteen V. Disease and acetylator polymorphism. In: Gibaldi M, Prescott L, eds. Handbook of clinical pharmacokinetics. Australia: Adis Health Science Press, 1983.

8 Price Evans D A. An improved and simplified method of detecting the acetylator phenotype. J Med Genet 1969; 6: 405-7.

9 Fischer C, Klotz U. Is plasma level monitoring of sulfasalazine indicated in the treatment of Crohn's disease or ulcerative colitis? Ther Drug Monit 1980; 2: 153-8.

10 Schroder H, Price Evans D A. Acetylator phenotypes and adverse effects of sulphasalazine in healthy subjects. Gut 1972; 13: $278-84$.

11 Das K M, Eastwood M A, McManus J P A, Sircus W. The metabolism of salicylazosulphapyridine in ulcerative colitis Gut 1973; 14: 631-41.

12 Azad Khan A K, Howes D T, Piris J, Truelove S C. Optimum dose of sulphasalazine for maintenance treatment in ulcerative colitis. Gut 1980; 21: 232-40.

13 Azad Khan A K, Truelove S C, Circulating levels of sulphasalazine and its metabolites and their relation to the clinical efficacy of the drug in ulcerative colitis. Gut 1980; 21: 706-10.

14 Das K M, Eastwood M A, McManus J P A, Sircus W. Adverse reactions during salicylazosulfapyridine therapy and the relation with drug metabolism and acetylator phenotype. $N$ Engl J Med 1973; 289: 491-5.

15 Pullar T, Hunter J A, Capell H A. Sulphasalazine in rheumatoid arthritis : the relationship of dose and serum levels to efficacy. BrJ Rheumatol (in press).

16 Das K M, Eastwood M A. Acetylator polymorphism of sulfapyridine in patients with ulcerative colitis and Crohn's disease. Clin Pharmacol Ther 1975: 18: 514-20.

17 Schroder H. Simplified method for determining acetylator phenotype. Br Med J 1972; ii: 506-7.

18 Eidus L, Hodgkin M M. Simplified screening test for phenotyping of isoniazid inactivators. Int J Clin Pharmacol Ther Toxicol 1973; 7: 82.

19 Crook P R, Hortas C, Roberts E J M, et al. Acetylator phenotype and the effect of dapsone in rheumatoid arthritis. $J$ Rheumatol 1983; 10: 805-8.

20 Pullar T, Hunter J A. Capell H A. Which component of sulphasalazine is active in rheumatoid arthritis. $\mathrm{Br}$ Med $\mathrm{J}$. 1985; 290: $1535-8$

21 Lawson D H, Henry D A, Lowe J, Reavey P, Rennie J A N, Solomon A. Acetylator phenotype in spontaneous SLE and rheumatoid arthritis. Ann Rheum Dis 1979; 38: 171-3. 